\title{
EHMTI-0326. OnabotulinumtoxinA for the treatment of chronic paroxysmal hemicrania: a case report
}

\author{
D Dolezil
}

\author{
From 4th European Headache and Migraine Trust International Congress: EHMTIC 2014 \\ Copenhagen, Denmark. 18-21 September 2014
}

\section{Introduction}

Chronic paroxysmal hemicrania $(\mathrm{CPH})$ is characterized by attacks of very severe, unilateral pain, fulfilling criteria of The International Classification of Headache Disorders, 3rd edition, beta version ( ICHD-3 beta) for paroxysmal hemicrania and occurring without a remission period, or with remissions lasting $<1$ month, for at least 1 year.

\section{Aims}

OnabotulinumtoxinA is now used for the treatment of chronic migraine.We wanted to try the treatment of $\mathrm{CPH}$ with OnabotulinumtoxinA, because other treatments have not been effective.

\section{Patient and methods}

We present the case of a patient diagnosed with $\mathrm{CPH}$ that lasts for 32 years. Attacks of headache lasted about 15 years without remission. The patient described her headaches as attacks of hemicrania lasted from 15 to 25 minutes with a frequency usually 8 times per day. OnabotulinumtoxinA was infiltrated at eight ipsilateral points. Total dose was 45 units (each intramuscular injection site was $0.1 \mathrm{~mL}=5 \mathrm{U}$ onabotulinumtoxinA). Seven points were identical as in the treatment of chronic migraine in the frontal and temporal areas and one point was in infraorbital area.Method applications of onabotulinumtoxinA based on the methodology of application of onabotulinumtoxinA in patients with chronic migraine.

\section{Results}

The $\mathrm{CPH}$ showed a dramatic response to onabotulinumtoxinA infiltration. Effect of treatment was evident as early as three weeks after the first injection, gradually

Prague Headache Center, DADO MEDICAL s.r.o., Prague 2, Czech Republic improved, it takes seven months from start of treatment with 3-monthly infiltrations.

\section{Conclusions}

The treatment of $\mathrm{CPH}$ with OnabotulinumtoxinA significantly improved the quality of life of the patient.

Published: 18 September 2014

doi:10.1186/1129-2377-15-S1-C16

Cite this article as: Dolezil: EHMTI-0326. OnabotulinumtoxinA for the treatment of chronic paroxysmal hemicrania: a case report. The Journal of Headache and Pain 2014 15(Suppl 1):C16.

Submit your manuscript to a SpringerOpen ${ }^{\circ}$ journal and benefit from:

- Convenient online submission

- Rigorous peer review

- Immediate publication on acceptance

- Open access: articles freely available online

- High visibility within the field

Retaining the copyright to your article

Submit your next manuscript at $>$ springeropen.com (c) 2014 Dolezil; licensee Springer. This is an Open Access article distributed under the terms of the Creative Commons Attribution License (http://creativecommons.org/licenses/by/2.0), which permits unrestricted use, distribution, and reproduction in any medium, provided the original work is properly cited. 